\title{
Thymectomy in Acute Systemic Lupus Erythematosus and Rheumatoid Arthritis
}

\author{
J. A. MILNE,* M.B., M.R.C.P., F.R.C.P.ED., F.R.C.P.GLASG, M.C.PATH. \\ J. R. ANDERSON, $†$ M.D., M.R.C.P., F.R.C.P.GLASG., M.C.PATH. \\ R. N. MACSWEEN, $\ddagger$ M.B., M.R.C.P.ED., M.R.C.P.GLASG. ; K. FRASER,§ M.D., CH.M., F.R.C.S.ED., F.R.C.S.GLASG. \\ I. SHORT,\| M.B., F.R.C.P.GLASG., M.R.C.P. ; J. STEVENS, M M.D., F.R.C.S., F.R.C.S.ED., F.R.C.S.GLASG. \\ G. B. SHAW,** M.B., B.SC., F.R.C.P.LOND.\&GLASG., M.R.C.P.ED. ; H. I. TANKEL,†† M.D., F.R.C.S.ED.
}

Brit. med. 9., 1967, 1, 461-464

Much of the mystery surrounding the function of the thymus gland was dispelled by the demonstration that its removal shortly after birth resulted in an impaired capacity to respond to various antigenic stimuli, including tissue homografts and injections of bacteria and of foreign proteins (Archer and Pierce, 1961 ; Miller, 1961).

These observations have now been made in several mammalian species, and it is well established that the thymus plays a vital part in the development of the lymphoid tissues and of normal immune responses: much of the evidence has been reviewed by Miller et al. (1962) and is described in a recent symposium (Good and Gabrielsen, 1964).

There is good evidence that the thymus secretes a humoral factor capable of stimulating lymphopoiesis in other lymphoid tissues (Levey et al., 1963 ; Osoba and Miller, 1964), and it is also likely that it produces large numbers of lymphocytes (Nossal and Gorrie, 1964 ; Sainte-Marie and Leblond, 1964), though this has not been established with certainty.

Though the thymus undergoes involution in adult life, lymphocytic mitotic activity, while not as prominent as in early life, maintains a high level, and in recent observations Metcalf (1965), Miller (1965), Miller et al. (1965), and Taylor (1965) provide evidence that thymectomy in the adult mouse is followed after an interval of several months by a depression of immune responsiveness.

Apart from thymic tumours, the only condition for which thymectomy is commonly performed in man is myasthenia gravis. The changes in the thymus in this condition commonly include the formation of germinal centres, and both this and the demonstration of immunoglobulin (IgG) in the thymus in myasthenia (White and Marshall, 1962) suggest that it may be the site of an abnormal immune response. The detection of auto-antibodies reacting with skeletal muscle in the serum of some patients with myasthenia raises the further possibility that the abnormal response is of an autoimmune nature. The thymus has not been studied extensively in the various other diseases in which auto-antibodies are commonly present, but thymic abnormalities, including formation of germinal centres, have been described in some cases of Hashimoto's disease, thyrotoxicosis, Addison's disease, systemic lupus erythematosus,

\footnotetext{
* Dermatology Department, Western Infirmary and Glasgow University,

Glasgow.
t Department of Pathology, Western Infirmary and Glasgow University,
Glasgow. Present address: Department of Pathology, University of Glasgow. Present address: Department of Pathology, University of ¥ Department of Pathology, Western Infirmary and Glasgow University, Glasgow.

Department of Surgery, Western Infirmary, Glasgow.

11 Department of Medicine, Western Infirmary, Glasgow. epartment of Orthopaedics, Western Infirmary and Glasgow Univer-
sity, Glasgow. Present addreas: Cook County Hospital, 1825 West Harricon Strees, Chicago, Illinnis.

** Department of Medicine, Southern General Hospital, Glasgow.

t+ Department of Surgery, Southern General Hospital, Glasgow.
}

and rheumatoid arthritis (Burnet and Mackay, 1962 ; Miller, 1963 ; Gunn et al., 1964 ; Hutchins and Harvey, 1964).

There is thus evidence that the thymus is the site of abnormal immune responses in the various conditions commonly termed autoimmune diseases, and it seemed possible that thymectomy might be of therapeutic value in these conditions. There is no reason to consider the operation in thyrotoxicosis, Hashimoto's disease, or Addison's disease, for which effective modes of therapy are available, but in some cases of systemic lupus erythematosus the poor prognosis is not greatly altered by the currently used therapeutic measures; rheumatoid arthritis is sometimes equally resistant to treatment, progressing relentlessly and painfully to severe disability. In such cases a trial of thymectomy seemed justifiable, and indeed two cases of systemic lupus in which thymectomy was performed have already been reported (Mackay and de Gail, 1963 ; Mackay et al., 1963). In the present paper we describe the results of thymectomy in three cases of systemic lupus and two cases of rheumatoid arthritis. Four of the cases were selected because of the failure of conventional therapy to control the disease, while the fifth case was chosen in an attempt to minimize renal damage.

\section{Operation}

A vertical mid-line incision was used to expose the sternum, which was split vertically by means of Lebsche's chisel. The two halves of the sternum were then separated by two Holmes Sellors combined separators and approximators. All the fat in the anterior mediastinum was removed along with the thymus gland, which generally showed the typical H-shaped structure, having two longer inferior processes and two shorter superior ones, the latter often extending to the thyroid gland. One or two tiny arterial branches were commonly found and ligated. There was always at least one small vein entering the innominate vein, as it lies transversely behind the thymic gland. If either pleural cavity was opened into (and this was apt to happen during an attempt to remove the fat adherent to the pleural sacs) it was drained, and if both pleural sacs were opened two drains were inserted and passed on to underwater seal drainage, the inlet tubes of each being connected by a $\mathrm{Y}$ tube in order to maintain an even pressure in the two sides. If the pleural sacs were not opened an anterior mediastinal drain was used. The sternum was brought together with three or four wire sutures, and these were reinforced with interrupted linen-thread stitches drawing the overlying aponeurosis together. The wound was then closed.

\section{Case 1}

A woman aged 41 was first seen in September 1956 and a diagnosis of chronic discoid lupus erythematosus was made. There was 
then no evidence of systemic involvement. In March 1961 her condition deteriorated, and for the first time the L.E. cell test was positive and her E.S.R. had risen to $48 \mathrm{~mm}$. (Wintrobe). Treatment with corticosteroids brought temporary improvement, but a further exacerbation in 1962 was associated with albuminuria. Despite treatment with corticosteroids her condition continued to worsen. On admission to hospital on 2 July 1963 she had an extensive erythematous rash on face, arms, and hands; blood examination showed $\mathrm{Hb} 10 \mathrm{~g} . / 100 \mathrm{ml}$. and W.B.C. 3,000/c.mm. with a preponderance of lymphocytes. The blood pressure was 180/105 and the urine contained albumin ( 5 parts Esbach). The L.E. cell test was strongly positive and the immunofluorescence test revealed the "speckled" pattern of nuclear staining in a titre of 1 in 1,000 . This latter result is indicative of antibody to a saline-soluble protein of the nucleus (Beck, 1961). Failure to detect the homogeneous staining pattern indicative of antibody to nucleohistone was surprising in view of the positive L.E. cell test, but the strong speckled staining may well have obscured weaker homogeneous staining of the nuclei.

Thymectomy was performed on 8 July. On 13 July the rash was noted to be fading and the albuminuria diminishing, and by 21 July the albumin had fallen to part Esbach. Steroids had been reduced slowly and were withdrawn on 23 July, by which time albuminuria had decreased. The patient was discharged from hospital on 31 July virtually free from rash and with only a trace of albumin in the urine. The L.E. cell test was positive and there were no changes in the pattern or titre of antinuclear antibodies at this time.

The patient was again admitted to hospital on 4 September 1963, with an extensive erythema and purpura over the entire body. She stated that two weeks previously she had developed "phlebitis" and had been treated with tetracycline and phenylbutazone. On examination her blood pressure was 120/80, albuminuria 9 parts Esbach, Hb 10 g., W.B.C. 2,800. The L.E. cell test was negative. For this episode she was treated with prednisolone, $80 \mathrm{mg}$. daily, reducing rapidly to $10 \mathrm{mg}$. daily. She remained reasonably well for a time, but by March 1964 was complaining of tiredness, weakness, and return of the rash on her face and hands. She was readmitted and was found to have a blood pressure of 195/120 with increased albuminuria (12 parts Esbach). Blood urea was $25 \mathrm{mg} . / 100 \mathrm{ml}$. Prednisolone was increased to $30 \mathrm{mg}$. daily, gradually reducing to $10 \mathrm{mg}$. daily, together with bed-rest and sedation, and on discharge on 20 April her blood pressure had fallen to $140 / 85$ and her albuminuria to 1 part Esbach. At this time the titre of antinuclear antibody was 1 in 256 (previously 1 in 1,000): it is doubtful whether this fall of titre is of any significance, as the degree of accuracy of such titrations is not high. The W.B.C. was 3,700 , mainly polymorphonuclears with a distinct lymphopenia.

TABLE I

\begin{tabular}{|c|c|c|c|c|c|}
\hline $\begin{array}{l}\text { Case } \\
\text { No. }\end{array}$ & Age & Diagnosis & $\begin{array}{l}\text { Pre-operative } \\
\text { Steroid Dosage }\end{array}$ & $\begin{array}{l}\text { Post-operative } \\
\text { Steroid Dosage }\end{array}$ & $\begin{array}{c}\text { Apparent } \\
\text { Effect of } \\
\text { Thymec- } \\
\text { tomy }\end{array}$ \\
\hline 1 & 41 & $\begin{array}{l}\text { Systemic lupus } \\
\text { erythematosus }\end{array}$ & $\begin{array}{l}30-50 \mathrm{mg} \text {. } \\
\text { prednisolone daily }\end{array}$ & $\begin{array}{l}\mathrm{Nil}-80 \mathrm{mg} \\
\text { prednisolone daily } \\
-10-30 \mathrm{mg} \text {. daily }\end{array}$ & Doubeful \\
\hline 2 & 22 & $" \quad "$ & $\begin{array}{l}20-45 \mathrm{mg} \text {. } \\
\text { prednisolone daily }\end{array}$ & $25 \mathrm{mg} \cdot-\mathrm{nil}$ & Good \\
\hline 3 & 22 & " & Nil & $\begin{array}{l}30-60 \mathrm{mg} \text {. } \\
\text { prednisolone daily }\end{array}$ & Poor. \\
\hline 4 & 32 & $\begin{array}{c}\text { Rheumatoid } \\
\text { arthritis }\end{array}$ & $\begin{array}{l}15 \mathrm{mg} \text {. } \\
\text { prednisolone daily }\end{array}$ & $\begin{array}{l}5 \mathrm{mg} . \\
\text { prednisolone daily }\end{array}$ & Good \\
\hline 5 & 21 & " & $\begin{array}{l}15-40 \mathrm{mg} \text {. } \\
\text { prednisolone daily }\end{array}$ & $\begin{array}{l}15 \mathrm{mg} \text {. } \\
\text { prednisolone daily }\end{array}$ & \\
\hline
\end{tabular}

Treatment with cyclophosphamide was attempted, but the patient was unable to tolerate the drug.

At the time of writing the patient was reasonably well, with minimal albuminuria. The L.E. rash still showed some activity on the face and hands, and her E.S.R. was still slightly raised $(18 \mathrm{~mm}$.). Her blood pressure had risen to $200 / 110$ and she had a grade II retinopathy. Her steroids were maintained at $30 \mathrm{mg}$. daily.

\section{Case 2}

A woman aged 22 was first seen at the Southern General Hospital, Glasgow, in May 1963, complaining of pain and swelling of elbows, wrists, and fingers, and was admitted for investigation as a possible case of rheumatic fever.

She was found to have a low-grade fever $\left(99^{\circ} \mathrm{F}\right.$; $37.2^{\circ} \mathrm{C}$.). Her E.S.R. was $82 \mathrm{~mm}$., Hb 7.4 g., and her W.B.C. 9,400. The RoseWaaler and L.E. cell tests were positive. Fluorescent antibody titre was 1 in 256 (speckled). Liver-function tests showed a sligh decrease in albumin (albumin $3.3 \mathrm{~g}$., globulin $3.5 \mathrm{~g} .100 \mathrm{ml}$.). $\mathrm{ZnSO}_{4}$ turbidity was 18.8 units. Electrophoresis showed marked increase in gammaglobulin. Treatment was begun with $45 \mathrm{mg}$. of prednisolone daily and Plaquenil (hydroxychloroquine) $400 \mathrm{mg}$ daily. She showed moderate improvement, and on 29 August prednisolone was reduced to $30 \mathrm{mg}$. daily and on 19 September to $20 \mathrm{mg}$. daily. On her next visit (10 October) there was some worsening of the condition, with slight joint pain in the left hand and shoulder. Prednisolone was therefore increased to $25 \mathrm{mg}$. daily On this dose her symptoms eased. However, in view of her youth and the development of side-effects from the relatively high maintenance dose of steroid required, and because of the presence of intermittent albuminuria, she was admitted on 9 February 1964 for thymectomy. This was performed on 14 February.

Her postoperative course was uneventful and the steroid dosage was tapered down slowly and finally stopped on 15 May. At this time liver function appeared normal (albumin $4.6 \mathrm{~g}$., globulin $2.2 \mathrm{~g}$.) apart from a slightly raised $\mathrm{ZnSO}_{4}$ turbidity (12.8 units). The fluorescent antibody titre was still 1 in 256. An occasional L.E cell was seen. Rose-Waaler test was negative. On 1 June she reported aching in wrists, fingers, and shoulders, her E.S.R. was $36 \mathrm{~mm}$., and albuminuria was present. Prednisolone was restarted at $15 \mathrm{mg}$. daily and was again tapered off in three weeks' time.

In November 1964 she was symptom-free, her E.S.R. was normal, and W.B.C. 7,200 (lymphocytes 33\%). Latex L.E. test (Hyland) was negative, but the fluorescent antibody titre had risen to 1 in 1,000 In January 1965 her E.S.R. was 30 mm., Hb 13.4 g., W.B.C. 5,600 (lymphocytes $50 \%$ ). Fluorescent antibody titre was 1 in 256. This variation in titre, as in Case 1, is probably related to low sensitivity of the method.

\section{Case 3}

A woman aged 22 was seen in January 1964 with joint symptoms and $a$ rash on the face, arms, and hands having the characteristics of lupus erythematosus. There was pain, swelling, and tenderness in the knees. White blood cells were 2,900 . L.E. cell tests were positive. She had albuminuria, and renal biopsy showed appearances consistent with the diagnosis of systemic lupus exythematosus. The blood urea was $33 \mathrm{mg}$. Antibody to deoxyribenucleoprotein was shown by the immunofluorescence test to be present in a titre of 1 in 64 .

In an attempt to halt renal damage thymectomy was performed on 21 February 1964 . The postoperative course was stormy, with a staphylococcal infection which necessitated resuture of the wound and wiring of the sternum. During this period she became rather drowsy with a suggestion of right-sided facial weakness. In view of the possibility of involvement of the nervous system she was started on $60 \mathrm{mg}$. of prednisolone daily on 12 March. After this her condition improved steadily apart from an infection of the urinary tract, which responded to antibiotic therapy. The steroid was reduced to $30 \mathrm{mg}$. daily and she was allowed home on 14 April.

Since then her condition has fluctuated somewhat, with a general downward trend, her blood pressure, albuminuria, and nitrogen retention gradually increasing. In November 1964 she was readmitted to hospital with pneumonia. Blood pressure was 220/ 140 , W.B.C. 14,000, and blood urea $114 \mathrm{mg}$. She also complained of vomiting and epigastric pain, due to a duodenal ulcer related to her steroid therapy. By this time she also had a gross Cushing facies. The pneumonia responded to tetracycline, and, in view of the progressive hypertension, steroid therapy was discontinued and methyldopa, $750 \mathrm{mg}$. daily, begun. Following this there was a marked rise in blood urea to $240 \mathrm{mg}$. At this point treatment with cyclophosphamide was begun and she was given $3 \mathrm{~g}$. intravenously over a period of two weeks with considerable clinical improvement. Blood urea was $74 \mathrm{mg}$., and the blood pressure had fallen to $190 / 120$ in response to treatment with methyldopa, $750 \mathrm{mg}$. daily.

Cyclophosphamide, $100 \mathrm{mg}$. orally daily, was continued until midJanuary 1965, when it was reduced to $50 \mathrm{mg}$. daily. Nost of her 
hair had by this time fallen out and a wig was supplied. By June 1965 her $\mathrm{Hb}$ was down to $7.5 \mathrm{~g}$. and W.B.C. 700. Cyclophosphamide therapy was discontinued and she was transfused with 4 pints (2.3 litres) of blood, which raised the $\mathrm{Hb}$ to $11.6 \mathrm{~g}$., the W.B.C. gradually rising to 2,000 . Blood urea was $54 \mathrm{mg}$.

Since then her improvement had been maintained and she was able to do her housework. She had no rash, joint pains, or urinary symptoms. When last seen in October 1965 she was well and her hair had completely regrown. Blood pressure was 170/120, Hb 13 g., E.S.R. $22 \mathrm{~mm}$., W.B.C. 3,600, and blood urea $68 \mathrm{mg}$. She was on no therapy other than methyldopa, the dose of which has been decreased to $500 \mathrm{mg}$. daily. Albuminuria persisted.

\section{Case 4}

A man aged 32 developed acute rheumatoid arthritis in 1957. During the next four years the arthritis was particularly severe and he was in hospital for periods totalling about two years. He was treated with short courses of A.C.T.H. and corticosteroids, as well as salicylates and phenylbutazone. The Rose-Waaler test was positive and the L.E. cell test negative.

By 1961 there was considerable destruction of many joints, and during the next two years reconstructive surgery was performed on the elbows, wrists, feet, left hand, and left hip. There was no remission during this time, the E.S.R. being persistently greater than $40 \mathrm{~mm}$. and the haemoglobin remaining about $10 \mathrm{~g}$. Because of the progressive and destructive nature of his disease he was started on prednisolone, $15 \mathrm{mg}$. daily, in 1962, and this was continued until thymectomy was performed in December 1963.

Intensive investigation during the month before operation confirmed the high sedimentation rate; the haemoglobin level and leucocyte count were normal, the Rose-Waaler test was positive, and the L.E. cell test was negative. The immunofluorescence test for antinuclear antibodies was also negative. By now his activities were grossly restricted: he could dress himself only very slowly and with great difficulty, and could walk about 50 yards (47 metres) with elbow crutches.

His postoperative recovery was marred only by an exacerbation of generalized joint pain lasting for three weeks. Thereafter his general condition slowly improved and his prednisolone dosage was gradually decreased. Four months after operation his sedimentation rate and haemoglobin were normal, he was able to walk 50 yards without support, and he was taking $5 \mathrm{mg}$. of prednisolone daily. At the time of writing he had maintained his improvement and suffered much less spontaneous pain. The W.B.C. was 7,200, with $55 \%$ lymphocytes.

\section{Case 5}

A man aged 21 was first seen in another hospital in 1960 with severe acute rheumatoid arthritis. Salicylates had no effect on the condition or the E.S.R. The Rose-Waaler test was positive and the L.E. cell test negative. He was treated with prednisolone and responded well initially. In spite of continuing treatment, however, his condition deteriorated after his discharge from hospital. In December 1962 he had a perforated duodenal ulcer treated surgically and in June 1963 a severe haematemesis treated by transfusion without recourse to surgery. Attempts to reduce the dose of prednisolone resulted in exacerbations, and in spite of treatment his arthritis progressed to extensive joint-destruction with severe pain.

In view of this history it was decided to try the effect of thymectomy, and he was admitted to the Western Infirmary in October 1964. On admission both shoulders, elbows, knees, wrists, and ankles were seen to be affected, and walking was extremely slow and painful. $\mathrm{Hb}$ was 10 g., E.S.R. $30 \mathrm{~mm}$., and W.B.C. 11,500. L.E. cell tests were negative and antinuclear factors were not detected.

Thymectomy was performed on 2 November 1964 . There has been no improvement in the clinical condition since this. Movement is as restricted as before operation, and despite several attempts to reduce the dose of steroids this has proved impossible because of severe pain and further limitation of movement. When he was last seen the E.S.R. was $30 \mathrm{~mm}$., Hb 9.4 g., and W.B.C. 10,000. It is hoped to readmit this patient for cyclophosphamide therapy in the near future.

The main features of these cases are summarized in Table I.

\section{Pathology of the Excised Thymus Glands}

The histological features of the thymus glands will be described in detail elsewhere. The main features may be summarized as follows.

Degree of Involution.-The thymic glands appeared grossly normal. Examination of multiple histological sections showed marked variation in the degree of involution. The gland from Case 4 was most severely involuted, consisting of very small areas of thymic tissue widely separated by fatty tissue. The gland from Case 5 showed least involution, consisting of approximately $30 \mathrm{~g}$. of thymic tissue, including, of course, interlobular adipose tissue.

It is of interest that the gland from Case 3-the only patient not treated with corticosteroids prior to operation-showed more pronounced involution than that from Case 2 , a patient of the same age who had received steroid therapy for some six months before operation.

Cortex.-Cortical tissue was discernible in all the glands, although in Cases 3 and 5 it formed a rather thin, discontinuous layer. No mitoses were seen in the cortex of any of the glands; mast cells were seen in all glands, particularly in the outer part of the cortex, but preliminary counts did not suggest that they were increased in number. Occasional Russell bodies were seen in the cortex in all the S.L.E. cases and in Case 5, while a few plasma cells were found in Cases 3 and 5 .

Medulla.-Apart from Case 2, in which the medulla of the thymus was markedly atrophic, the amount of medullary tissue was disproportionately great when compared with the cortex. Germinal centres, surrounded by a zone of tightly packed lymphocytes, were seen in the medulla of all glands except that in Case 4. In Cases 1, 2, and 3 these centres were relatively few and small when compared with those observed in the thymus in most cases of myasthenia gravis, but their activity is indicated by numerous mitotic figures. In Cases 1,2 , and 3 the medulla also contained other round or oval areas which had relatively few cells and no mitoses: the appearances are similar to those regarded by Burnet and Mackay (1965) as inactive germinal centres. In Case 5 the thymus contained larger and more numerous germinal centres than in the other cases, the appearances resembling those seen in myasthenia gravis.

Hassall's corpuscles were present in all the thymus glands. In Case 2 they were unusually large and cystic, being lined often by a single layer of cells enclosing amorphous eosinophilic material. No abnormality was noted in the arrangement of reticulin fibres and medullary blood-vessels, the appearances resembling those described by Sainte-Marie and Leblond (1964) in the thymus of young rats.

The main features of the excised thymus glands are summarized in Table II.

\begin{tabular}{|c|c|c|c|c|c|c|}
\hline $\begin{array}{l}\text { Qase } \\
\text { Na }\end{array}$ & $\begin{array}{l}\text { Thymic } \\
\text { Weight } \\
\text { (Gross } \\
\text { Specimen) }\end{array}$ & $\begin{array}{l}\text { Degree of } \\
\text { Involution }\end{array}$ & $\begin{array}{c}\text { Cortical } \\
\text { Remnants }\end{array}$ & $\begin{array}{c}\text { Germinal } \\
\text { Centres }\end{array}$ & $\begin{array}{c}\text { Plasma } \\
\text { Cells }\end{array}$ & $\begin{array}{l}\text { Russell } \\
\text { Bodies }\end{array}$ \\
\hline $\begin{array}{l}1 \\
2 \\
3 \\
4 \\
5\end{array}$ & $\begin{array}{l}16 \mathrm{~g} . \\
36 \mathrm{~g} . \\
20 \mathrm{~g} . \\
5 \mathrm{~g} . \\
30 \mathrm{~g} .\end{array}$ & $\begin{array}{c}++t \\
+ \\
++ \\
+t+ \\
+\end{array}$ & $\begin{array}{l}+ \\
+ \\
+ \\
+\end{array}$ & $\begin{array}{l}+ \\
+ \\
+\end{array}$ & $\frac{\bar{m}}{ \pm}$ & $\begin{array}{l}+ \\
+ \\
+\end{array}$ \\
\hline
\end{tabular}

\section{Discussion}

The possibility that thymectomy might be of therapeutic value in these five cases was based upon the following premises: (a) that pathological changes in systemic lupus and rheumatoid arthritis result from immune reactions and $(b)$ that thymectomy might suppress the pathogenic immune responses.

There is no conclusive evidence for either of these possibilities, and in each case the decision to perform thymectomy 
was based upon the poor outlook in the cases of systemic lupus and the severe pain and progressive disability in the patients with rheumatoid arthritis, one of whom had also developed serious complications of steroid therapy.

The histological changes in the excised thymus glands were similar to those described by Burnet and Mackay $(1962,1965)$ in two cases of systemic lupus. The degree of cortical atrophy, although considerable, appeared less marked than in Burnet and Mackay's cases, and, unlike these authors, we do not feel justified in claiming an increase in the numbers of Hassall's corpuscles ; nor were plasma cells numerous in any of our cases, although in all except Case 4 either plasma cells or Russell bodies were seen in small numbers. Perhaps the most striking abnormality which could not be attributed to the non-specific effects of illness or steroid therapy was the presence of structures morphologically indistinguishable from lymphoid germinal centres. Assuming that these structures are indicative of an immune response within the thymus, Burnet and Mackay (1962) have suggested possible ways in which they may be concerned in the development of the autoimmune responses observed in systemic lupus. However, there is at present little firm evidence on which to assess their significance.

The only indirect evidence of any change after thymectomy in the immunological status of any of these cases is the development of lymphopenia in Case 1.

In view of the latent period of several months between thymectomy and subsequent suppression of immune responsiveness in adult mice (R.B. Taylor, personal communication, 1964), it may be that the effects of thymectomy in these patients will not become fully apparent for a long time. The results are difficult to assess at present, but in general it can be said that no dramatic benefit has resulted from removal of the thymus in any of these cases. The initial improvement postoperatively in Case 1 was probably due to the increase in steroids to cover the operation. The apparent alleviation of symptoms in Case 4 and "cure" in Case 2 may be related to natural variations in severity and remissions known to occur in these diseases. If one accepts Burnet and Mackay's hypothesis (1965) that the thymus is the origin of forbidden clones then it would seem rational to remove this source. However, this procedure would not of necessity, unless the autoimmune lymphoid cells are thymus-dependent, affect those forbidden clones which are already established in the lymphoid tissues of the body. These would have to be dealt with by some other means.

No disease with a natural history closely resembling that of systemic. lupus or of rheumatoid arthritis has yet been produced experimentally except by highly artificial means, and accordingly there is no good experimental model of these diseases which might be used to test out various forms of therapy. However, the disease which occurs spontaneously in hybrid mice of highly inbred strains $\mathrm{NZ} / \mathrm{BL}$ and $\mathrm{NZ} / \mathrm{W}$ (Helyer and Howie, 1963a) appears to possess features similar to those of systemic lupus, including the development of L.E. cell factor and of lupus-like glomerular lesions. The finding that this disease is not prevented by neonatal thymectomy, with or without replacement by the thymus gland of a neonatal mouse of a "normal" strain (Helyer and Howie, 1963b), suggests that the fundamental defect is not an intrinsic abnormality of the thymus. If the mouse disease and systemic lupus are basically the same, then the failure to demonstrate clearly the value of thymectomy in the five patients described is perhaps not surprising.

Our experience in Case 3 supports the recent reports on the value of cytotoxic drugs, such as cyclophosphamide, in the treatment of systemic lupus, though it remains possible that improvement in this case was due to the combination of thymectomy and cyclophosphamide.

Despite the apparent importance of the thymus in autoimmunity, it is clear that much further study is necessary to elucidate its possible role in the pathogenesis of the connectivetissue diseases.

\section{Summary}

Thymectomy was performed on three cases of acute disseminated lupus erythematosus and two cases of rheumatoid arthritis which were not responding to conventional therapy.

No significant clinical improvement was observed nor was there any appreciable change in the immunological status of the patients.

While it is admitted that the thymus is probably a major immunological organ, further work is necessary to assess its role in autoimmune disease.

We should like to thank Dr. T. Cochrane, Ayr, and Dr. J. B. Barr, Kilmarnock, for referring Cases 1 and 5 respectively.

ADDENDUM.-Since this article was submitted for publication Mackay and Smalley (1966) have reported in detail the results of thymectomy in three patients with systemic lupus erythematosus. These patients showed no immediate postoperative improvement and required full treatment with corticosteroids, but have remained in moderate-to-good health over observation periods of one to three years.

\section{REFERENCES}

Archer, O., and Pierce, J. C. (1961). Fed. Proc., 20, 26.

Archer, O. S. (1961). Lancet, 1, 1203.

Burnet, F. M., and Mackay, I. R. (1962). Ibid., 2, 1030.

Burnet. (1965). 9. Path. Bact., 89, 263.

Good, R. A., and Gabrielsen, A. B. (editors) (1964). The Thymus in Immunobiology. Hoeber, New York.

Gunn, A., Michie, W., and Irvine, W. J. (1964). Lancet, 2, 776.

Helyer, B. J., and Howie, J. B. (1963a). Nature (Lond.), 197, 197.

- (1963b). Lancet, 2, 1026.

Hutchins, G. M., and Harvey, A. M. (1964). Bull. Fohns Hop. Hosp.,

Levey, R. H., Trainer, N., and Law, L. W. (1963). ₹. nat. Cancer Inst., 31, 199 .

Mackay, I. R., and de Gail, P. (1963). Lancet, 2, 667.

Mackay, I. R., and de Gail, P. (1963). Lancet, 2, 667. Brit. med. F., 2,

792 .

Metcalf Smalley, M (1966). Clin. exp. Immunol., 1, 129.

Metcalf, D. (1965). Nature (Lond.), 208, 1336.

Miller, J. F. A. P. (1961). Lancet, 2, 748.

(1963). Brit. med. f., 2, 459

(1965). Nature (Lond.), 208, 1337.

de Burgh, P. M., and Grant, G. A. (1965). Ibid., 208, 1332.

Marshall, A. H. E., and White, R. G. (1962). Advanc. Immunol., 2, 111 .

2, 111 . J. V., and Gorrie, J. (1964). In The Thymus in Immunobiology, edited by R. A. Good and A. B. Gabrielsen, p. 288. Hoeber, New York.

Osoba, D., and Miller, J. F. A. P. (1964). 7. exp. Med., 119, 177

Sainte-Marie, G., and Leblond, C. P. (1964). Blood, 23, 275.

Taylor, R. B. (1965). Nature (Lond.), 208, 1334.

White, R. G., and Marshall, A. H. E. (1962). Lancet, 2, 120. 